Article

\title{
The Application of Information Technologies in Consideration of Augmented Reality and Lean Management of Enterprises in the Light of Sustainable Development
}

\author{
Helena Kościelniak *, Małgorzata Łęgowik-Małolepsza * and Sylwia Łęgowik-Świącik \\ The Management Faculty, Częstochowa University of Technology, Armii Krajowej 19B, \\ 42-201 Częstochowa, Poland; sylwia.legowik-swiacik@wz.pcz.pl \\ * Correspondence: helena.koscielniak@wz.pcz.pl (H.K.); malgorzata.legowik-malolepsza@wz.pcz.pl (M.Ł.-M.); \\ Tel.: +48-34-3250-330 (H.K.); +48-34-3250-330 (M.Ł.-M.)
}

Received: 1 March 2019; Accepted: 8 April 2019; Published: 11 April 2019

\begin{abstract}
The paper discusses the problem associated with the use of modern information technologies that take into account extended reality and the lean management culture to achieve sustainable development by enterprises, which is part of the field of management science. The subject is important and current due to the strong social need for the implementation of the concept of sustainable development. The aim of the article is to learn about and evaluate augmented reality and lean culture in the area of sustainable development management of enterprises. The concept of sustainable development is an approach that arouses great interest among management theoreticians, but many practitioners still do not know how to effectively realize it in changing conditions. Therefore, the paper proposes the application and the use of augmented reality and lean culture assumptions in the area of sustainable development management of enterprises. In the research, the authors emphasize that the sustainable approach to enterprise management should take into account the assessment of augmented reality (AR) and instruments of lean culture in the area of management since better understanding of the coexistence of benefits, compromises, opportunities and threats related to modern technologies allows for more efficient implementation of sustainable development management in enterprises. The paper has been divided into four parts. The first part presents the concept of sustainable development in the light of the literature research. The second part shows the essence of augmented reality as a modern information technology. The third part of the paper is devoted to the presentation of the concept of lean management in enterprises. The fourth part of the paper is the case study, in which the DHL enterprise report is related to, where the applied and utilized augmented reality and lean culture in shaping sustainable development are presented. The methods used to achieve the goal are: Literature studies, descriptive analysis and case study. The whole discussion is closed with the summary, which shows that the scope of application of augmented reality and lean culture in the area of sustainable development management of enterprises is unlimited.
\end{abstract}

Keywords: sustainable development; augmented reality; lean management; information technologies

\section{Introduction}

The considerations regarding the concept of sustainable development are relatively new and are subject to continuous evolution. Despite the growing interest, among theoreticians and practitioners in the management of the concept of sustainable development [1], the actions taken in the application of its principles are not adequate to the possibilities that enterprises have in the world [2] as well as in 
Poland [3]. In the literature on sustainable development, there is still a cognitive gap about the impact of modern information technologies that take into account augmented reality, on the one hand, and the lean culture assumption on the achievement of sustainable development by enterprises, on the other. Moreover, there is no research into the desired reinforcement of instruments of augmented reality which, by means of the construct, include the potential for shaping and strengthening the reality in a desirable manner so as to mitigate the negative consequences of unsustainable activities of enterprises.

Therefore, the study poses the research question: Does the application and use of augmented reality and assumptions of lean culture shape the sustainable development of enterprises? As a consequence of the question posed, the aim of the study has been to learn and evaluate augmented reality and lean culture in the area of sustainable development management of enterprises, which is part of the field of management science. In order to accomplish the objective of the paper, literature studies have been conducted; a descriptive analysis in terms of the application of augmented reality was performed and a case study was analyzed to corroborate findings.

\section{The Concept of Sustainable Development-The Literature Review}

\subsection{The Essence of Sustainable Development}

The concept of sustainable development has been popularized by the World Commission on Environment and Development. The Report of the World Commission on Environment and Development: Our Common Future [4], defines what sustainable development should be. The report emphasizes the search for sustainable development paths [5-7] that will enable finding multilateral solutions combining economic, environmental and social benefits. In this approach, the task of sustainable development is to meet the current needs of society without diminishing development opportunities for future generations [8,9]. Therefore, augmented reality and lean culture support sustainable development since it improves production processes, reducing the number of work accidents, pollution and the use of natural resources through continuous improvement and a better use of resources.

Over the years, the term 'sustainable development' has evolved. In the subject literature, the attention has been paid to the need of the analysis of the following systems: Economic, social and ecological, as well as simultaneous implementation of economic, social and ecological goals [10,11]. This means that the concept of sustainable development translates into material effects in order to maintain the long-term existence of people on earth [12-14] while balancing environmental needs with the need for development [15-17].

The concept of sustainable development aims to create a general structure that will enable the development of solutions in this field, combining environmental, social and economic needs. However, the pace of implementation of solutions for the concept of sustainable development in enterprises is slow. Moreover, it points to the need to develop more specific guidelines, enabling enterprises to effectively implement activities in a sustainable manner [18]. Therefore, in this study, the attention will be paid to environmental and social issues in the light of strategic management of enterprises. By focusing on the business approach while generating beneficial economic results, enterprises can simultaneously achieve environmental and social goals. This kind of strategy comprises both management orientation in sustainable development and the achievement of economic goals.

\subsection{The Economic Perspective of Sustainable Development}

The economic perspective of sustainable development consists in emphasizing value added, created by environmental and social activities and undertaken by enterprises. The evaluation of the level of value added, generated by environmental and social activities of enterprises, is the focus of interests of many researchers in the field of management [19-22]. The problem of the reconciliation of economic goals and environmental and social objectives in enterprises may have a complementary, competitive or irrelevant nature [20]. The complementary nature consists in the implementation of 
one type of goal, which makes the achievement of other goals impossible. The competitive nature occurs when the implementation of one type of objective prevents or limits the achievement of other goals. In the case when mutual influences between achieving different types of objectives cannot be observed, their nature, in the decision-making process, is irrelevant [20].

Understanding the concept of sustainable development from the economic perspective as well as social and environmental ones or its usability should be analyzed for the company's purposes. The implementation of environmental and social goals is justified by enterprises for two basic reasons. While the first reason may be connected with legislative factors, market pressure or other stakeholders, including owners, the second one emerges from the voluntary pursuit of sustainable development. This means that the need to integrate economic, environmental and social goals may be the result of specific normative conditions or ethical and economic rationality [22]. It should be noted, however, that normative conditions are most often introduced by the law. Nonetheless, ethical and economic rationality is implemented in enterprises on the basis of internal regulations, regardless of whether the actions taken for sustainable development are the result of internal coercion or combined with meeting competition and customer expectations [23].

While considering the economic perspective of sustainable development, it should be noted that the above-mentioned notion can affect the productivity and efficiency of enterprises. What is more, the implementation of environmental and social activities could also support the development of sustainable products and services and reduce the risks associated with negative impacts on the environment and society [22]. When undertaking environmental and social activities, in accordance with the concept of sustainable development, it should be noted that this improves the company's credibility, too. Benefits, resulting from the implementation of the concept of sustainable development, are reflected both in the improvement of economic results and an increase in competitiveness. The improvement of economic results may lead to the reduction of costs as well as sales growth. On the other hand, the rise in competitiveness may be the result of the enhanced customer satisfaction, an increase in innovation capacity or in the market share [21]. Thus, the insight into sustainable development may prove to be an important element of the business model, which allows to create value by looking for the best company results.

Yet, it should also be acknowledged that, in addition to the advantages, there are also the drawbacks of the economic perspective of the sustainable development implementation. The adoption of the economic perspective of sustainable development, focused on efficiency and generated by environmental and social activities, may lead to a situation in which, indeed, the efficiency of the operating activity of the company will improve in the short term. However, in the long run, it might cause a decline in the company's competitiveness in the market sector [24]. It is worth noticing that the economic perspective of sustainable development is also associated with the implementation of modern information technologies by enterprises, which may result in both positive and negative effects. The positive effect of the implementation of modern information technologies in the area of sustainable development can be a change in the media landscape, which will translate into the efficiency of sales of certain products. Moreover, the implementation of modern information technologies in the area of sustainable development will generate the positive consequence in the social perspective since they positively affect the quality of social relations [25]. However, there are also negative effects related to the risk of violating privacy and copyright [26].

Summing up, it is important that the benefits of the implementation of the economic perspective of sustainable development are perceived by managers in a broad sense, showing not only a positive impact on reducing costs or increasing revenues but also taking into account social and environmental expectations. Therefore, it is not hard to understand that the implementation of the assumptions of the concept of sustainable development is integrated with the company's organizational culture along with its strategy. 
2.3. The Significance of the Integration of Sustainable Development with the Enterprise Strategic Management System

The management system of sustainable enterprise development should be such a set of procedures which ensures the integration of sustainable development goals and transforms resources, at all levels of management, as shown in Figure 1. Setting sustainability goals results in establishing feedback which, in turn, is the effect of adaptation of the company's fair business and social values [27]. Organizational culture is the foundation for business management, particularly in the context of sustainable development [28]. It exerts a strong influence on taking actions towards the implementation of the assumptions of the sustainable development notion. An increase in sustainable development awareness in enterprises favors the use of more ambitious goals and strategies in this concept assumption implementation.

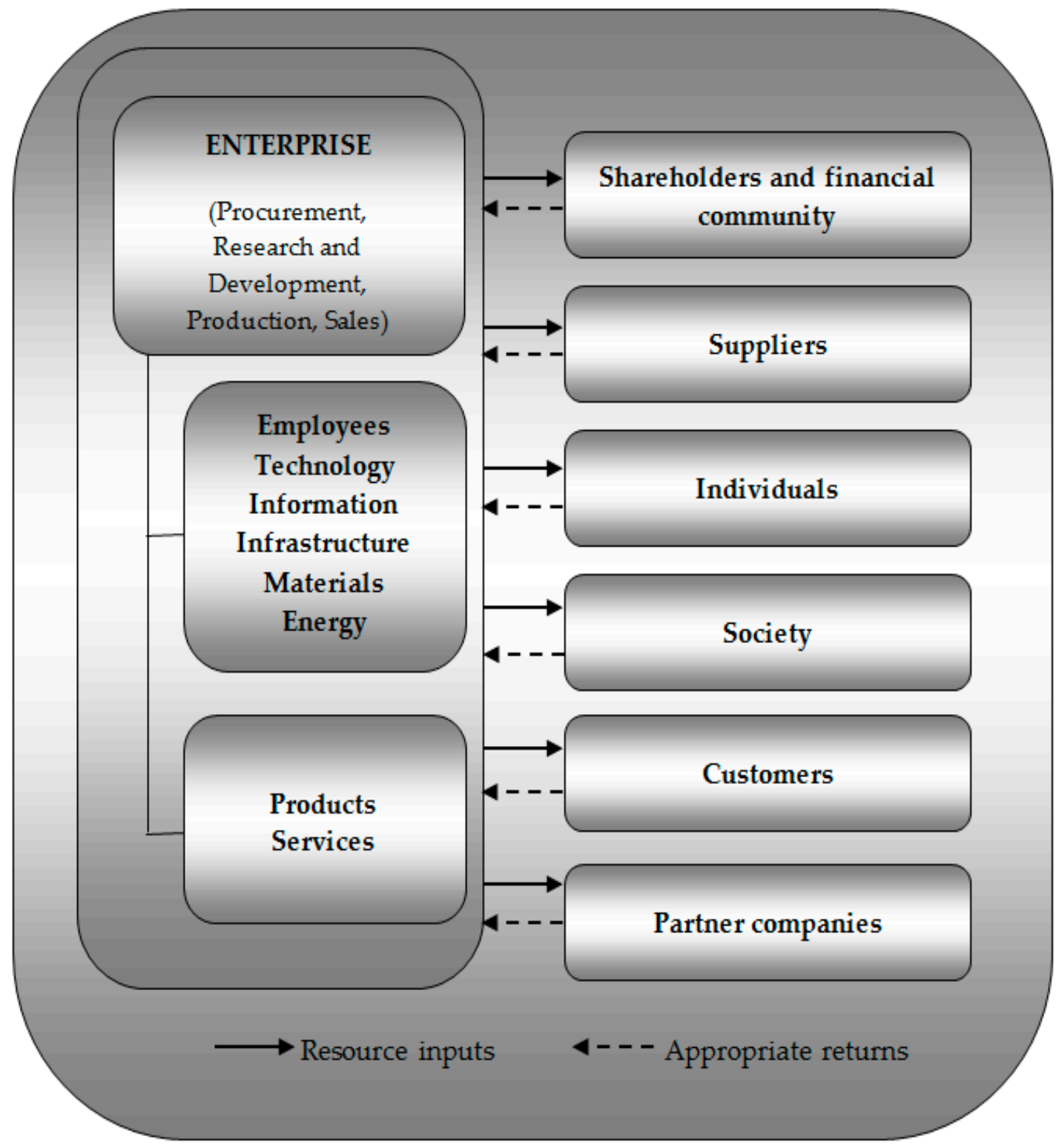

Figure 1. The enterprise as the system of resource transformation. Source: Development based on [29].

Various groups of stakeholders, who can support or hinder the implementation of the adopted assumptions, play an important role in the implementation of assumptions of the concept of sustainable development [30]. Therefore, the concept should be legal and valuable so as not to generate resistance 
from stakeholders. A credible policy of sustainable development management in enterprises allows for expanding business and increasing competitiveness, which results in better economic outcomes. In addition, a credible sustainability management policy is reflected in the social acceptance of the company's operations [22]. Substantially, authenticating the notion of sustainable development in enterprise management requires the integration of strategic interactions with the corporate chain, having an influence on sustainable development, which therefore improves the environmental and social performance of enterprises (Figure 2). This means that the company is ready to engage in establishing new products, structures and technologies that are the potential source of innovation [31]. In this regard, the implementation of the assumptions of the concept of sustainable development becomes a generator of innovation.

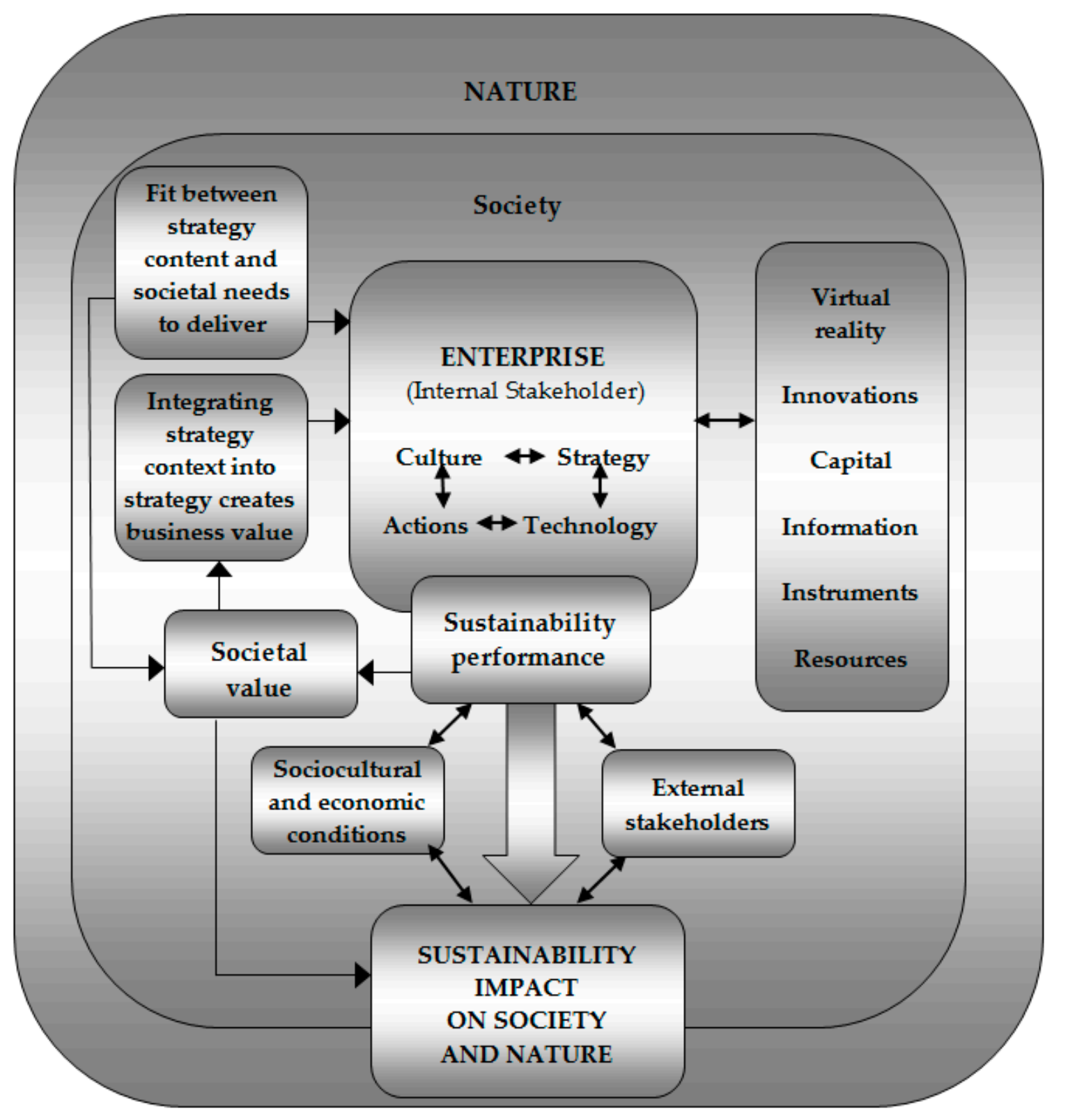

Figure 2. The perspective of sustainable development in enterprise management and strategic interactions with the corporate chain, having an influence on sustainable development. Source: Development based on [22].

Enterprises interested in creating innovative products made using "green technologies" allow for generating value added. Thus, the integration of sustainability combined with the product 
manufacturing process enables us to enhance customer satisfaction with a sustainable product, which translates well into economic results.

Summing up the review of the definition of sustainable development, it should be emphasized, that it is an ambiguous and multifaceted term. The concept of sustainable development, on the one hand, draws attention to the needs of future generations. On the other, it emphasizes the social dimension and technological development to improve living conditions. Thus, the concept of sustainable development is global and should be taken into account, not only by enterprises, but also by all types of organizations, regardless of the type of business.

\section{The Research Methodology}

In order to achieve the goal set in the study, the research process has been carried out using the method of literature analysis, descriptive analysis and the case study [32,33]. The literature analysis method is the first stage of scientific cognition. The essence of that method is to demonstrate purposefulness, originality and the new approach to the research goal chosen and undertaken. By means of this method, the authors want to present the current scientific achievements and point to the observed research gap. The method of the literature analysis also allows for familiarizing with the essence of the above-mentioned phenomenon. Therefore, the scientific cognition using the literature analysis method is compliant with defining the whole of the characteristics whose elimination would be equal to the destruction of the research object [34]. Moreover, the method of literature analysis enables indicating how the problem originates from the current state of knowledge on the subject. It points to differences, similarities, relationships, dependencies, essential features in the well-known scientific theories. In management science, it presents discrepancies in the existing hypotheses, research assumptions, ideas of action, beliefs and views.

The second method used in the study is the descriptive analysis method, based on the description of research activities used in the scientific research. It has a cognitive nature and adopts a descriptive function as the basic prerequisite for the characterization of the methods used. The use of this method allows for explaining which sequences of actions, norms and research rigor are the premise for the formulation of conclusions [34]. The descriptive analysis method consists of developing research instruments in the creation of hypotheses and their verification. It allows for searching for significant dependencies and relationships and their analysis.

The analytical research in management science aims to detect the structure and mechanisms of action. Therefore, the descriptive analysis has been used in the study to solve the research problem. The use of the descriptive analysis method to achieve the research objective allows for formulating synthetic conclusions. The conclusions are drawn on the basis of 'thought' operations, such as comparing, abstracting and generalizing. This approach allows the detection of new significant properties and dependencies. The above determines that the descriptive analysis method is a specific part of the research process.

However, it should be emphasized that the lack of empirical verification is the limitation of methods used to analyze and criticize literature and descriptive analysis. However, in the case of the research goal, which is to learn and assess augmented reality and lean culture in the area of sustainable development management of enterprises, it should be that this is the beginning. Therefore, its empirical verification requires time, which relates to the application of modern solutions by enterprises. As well as incurring costs for the implementation of empirical research on a large research sample. Therefore, at the subsequent stage of the research procedure, the case study method has been used to present an accurate and in-depth image of the phenomena and the relations studied [35]. It should be noted that the case study is the method with the probabilistic capability of scientific cognition [36] resulting from the intuitiveness and subjectivity of judgements, low representativeness of results, high time-consuming nature and costly research. However, the main advantage of carrying out the research process, using the case study, is to strive to develop the concept of the studied phenomenon as well as the in-depth interpretation. 


\section{Augmented Reality-The Use of the Modern Information Technology}

Modern managers, in order to take right decisions and to implement actions, use digital information available in the environment and in different IT (Information Technology) sources, which can also be applied for the implementation of the concept of sustainable development [37]. The development of modern technologies facilitates the access to digital sources of information. This means that the access to digital information is possible due to the so-called augmented reality (AR) [38,39], which is "a set of technologies which apply digital data and images onto the physical world" [40]. At the same time, the application of digital images and data onto real objects enables easier acquisition of information and its use in practice of the implementation of the concept of sustainable development in order to speedily reduce the negative effects of economic activities on the environment.

According to Carmigniami and Furht, AR is expanding the physical reality by adding to it an additional layer of information generated by the computer [41] R. T. Azuma defines augmented reality as a system which combines the real world with virtual reality, which is interactive in real time and enables the freedom of movement in three dimensions [42]. The term of virtual reality (VR) also requires explanation. W.S. Bainbridge defines virtual reality as the environment created with electronic devices which is to reflect the physical space in a complex manner so as to enable customers to establish interactions with other people and virtual objects [43].

In spite of the fact that augmented reality [44] is only developing, some enterprises, such as General Electric, Amazon or Facebook successfully make use of its tools in the implementation of the concept of sustainable development, which on the one hand increase customer confidence, and on the other hand, shorten the employees' working time, which translates into an increase in company profits. An example of the application of the AR technology is the game Pokemon Go, or car navigations whose maps are displayed digitally on the windshield showing the right way so that the digital image is applied directly on the real image (see Figure 3). The AR HUD (Head-Up Display) display, with its capabilities, supports a traditional GPS (Global Positioning System) whose operation forced the driver to take their eyes off the road and look at the map of the display of the GPS device and then translate the received information into the real image. An example of the VR technology is smart glasses, i.e. display units placed on the head in which their user can see an VR image and may communicate with it (see Figure 4). The combination of AR and VR technology is referred to as mixed reality (MR). It is a combination of real and virtual world, which aims to create new environments and visualizations [44]. All three characterized technologies (AR, VR, MR) form extended reality (XR), that is, for real and virtual connected environments that take into account human achine interactions, which are generated by computer technologies and devices for carrying [44]. Augmented reality presents data and information in three-dimensional images as opposed to the previously used two-dimensional way of presenting data, augmenting sustainable development outlets.

A good example of the application of augmented reality is referring to the traditional use of paper, two-dimensional assembly instructions concerning the assembly of different structures or diagrams illustrating the assembly. Standard instructions require their prior reading, completing the necessary components and alternate reading the instruction, analyzing the data read and processing them into the operation instruction.

On the other hand, augmented reality allows the use of interactive three-dimensional holograms presenting the way of performing individual assembly processes. The example referred to presents the advantage of AR consisting in the replacement of two-dimensional instructions and hints with three-dimensional holograms. According to the information in the field of literature on AR, time saving resulting from the application of the AR tools when implementing production tasks has been reduced on average by twenty-five per cent [40]. 


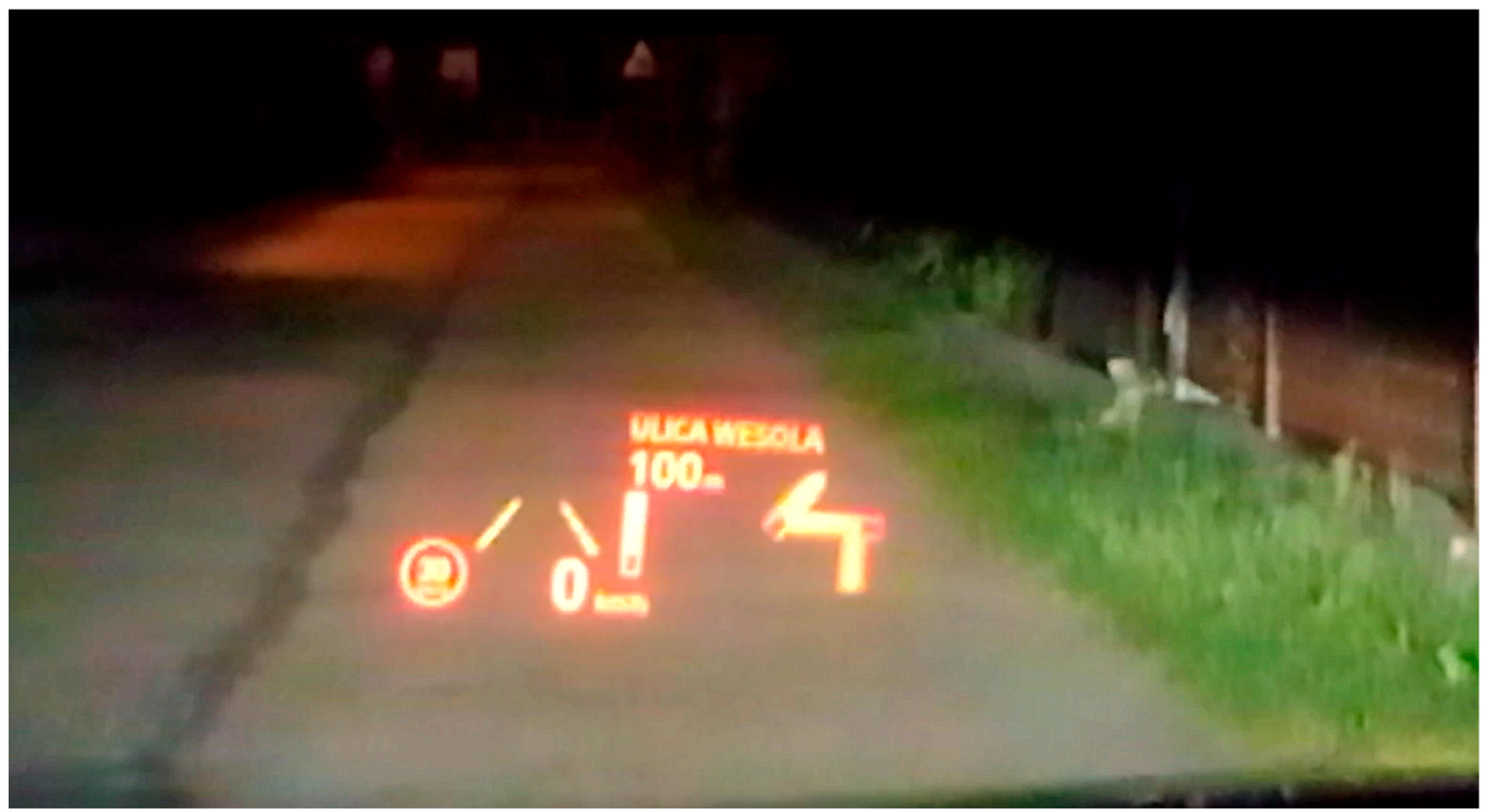

Figure 3. Car navigation whose map is displayed digitally on the windshield. Resource: Own elaboration.

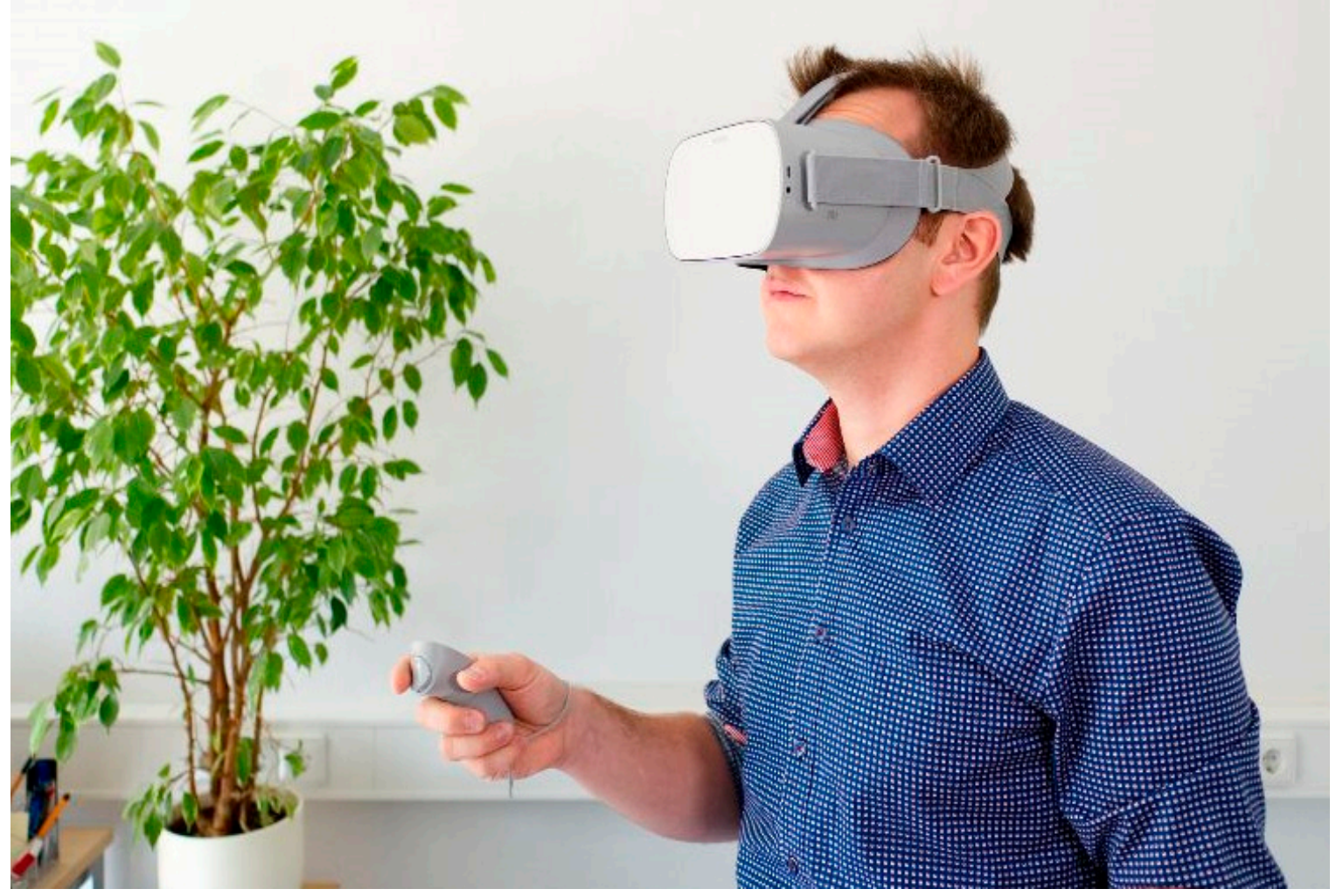

Figure 4. Smart glasses for virtual reality. Resource: https://pixabay.com/pl/vr-wirtualnarzeczywisto\%C5\%9B\%C4\%87-okulary-3411378/reading from 21.06.2018.

One of many advantages of the devices equipped with AR is the possibility to send the image created by the device to any other place. This allows some interactions of the receivers of the image and reduction in the need for the physical movement of the device users so that they can analyze the obtained image and, on its basis, make right decisions. Another benefit of AR is visualization which 
consists in the fact that the devices equipped with AR can show the properties or systems, instructions and simulations which allow for practicing safely dangerous maneuvers or tasks. When emphasizing the advantages of AR, it must be quoted that "this technology will considerably change the methods of training and developing skills, allowing people to perform complicated work without long-term and expensive conventional learning which for many is unavailable" [40].

The use of augmented reality [45] in production companies allows "the registration of information from automated and control systems, secondary sensors and asset management systems and presentation of important monitoring and diagnosed data on each machine or each process in the factory" [40]. Augmented reality [44,46] is designed primarily for smartphones and tablets. Devices equipped with AR can be controlled via voice, gesture or a touch screen and apply digital information on the physical world. AR solutions can be downloaded in the form of a digital application on a smartphone or a tablet due to which the user points the device at the object, then looks at it and the software identifies the object using the technology of recognizing the image and analyzing the stream of video data [47]. Subsequently, the device downloads the information to the object from the cloud [40]. This means that when observing the object with the device equipped with AR it is possible to access information characterizing the specific object. However, it should be noted that the implementation of AR will not work for all technologies. This reduces opportunities to use the potential of AR in enterprises that do not invest in a modern machine park.

Summing up, it should be noted that augmented reality is a modern information technology which provides additional information and data where they are needed, which affects sustainable development of enterprises. Augmented reality [48] changes the way of transmitting information. It allows for seeing more and combining the physical world with the virtual one, for example, the use of AR improves production processes in the area of maintenance, whose task is to ensure the efficiency of the technological sequence, which reduces the number of work accidents, reduces the amount of pollution and the use of natural resources. The use of the potential, which extended reality possesses in connection with the implementation of lean management culture, may be applied in shaping sustainable development of enterprises.

\section{The Concept of Lean Management in Enterprises}

The concept of lean management consists of continuous improvement in business management in order to reduce all possible operating costs, eliminate waste and increase the performance of the company, therefore it should also be implemented in the field of sustainable development of enterprises. The activities concerning lean management and at the same time "aiming at optimization in the field of the conducted activity may be implemented through the elimination of unnecessary actions and continuous improvement in operations required in the specific manufacturing cycle, which is the subject of interest of the lean management concept" [49]. Therefore, modern managers must "create new features, behavior, attitudes, which will constitute an adequate response to the globally transforming reality", also in the area of sustainable development [50,51].

Lean management is the culture of business management based on the Japanese approach developed in the Toyota company. In the 1940s, when the Toyota company experienced a financial crisis, a range of breakthrough production innovations were implemented which allowed the elimination of areas that were subject to losses and improvement in the core operations of the company [52,53].

The lean approach to management implemented by the Toyota company was popularized in 1990 when the authors James P. Womack, Daniel T. Jones and Daniel Roos published the book The Machine that Changed the World, in which they described the way of the operation of the lean enterprise [54].

Lean management [55] is an approach to enterprise management in a 'lean' way. This means that by organizing a sustainable production process, planning of material resources and maintenance of stocks of work in progress, finished products, materials and goods is approached in a cost-effective manner. Lean management of the enterprise [56] consists of the implementation, in the operation of the enterprise, a range of activities in order to optimize costs in response to the need of the enterprise 
to adjust to new market management conditions [57,58]. At the same time, the lean approach to management refers to "the production of products or services in line with customer expectations at minimum cost and optimum use of resources by eliminating waste in the whole area of business activity" [59].

The main instruments of the concept of lean management are: Kaizen, kanban, target costing, 5S, JIT, TQC, six sigma and many others [60,61]. Enterprises implement the listed tools in the area of sustainable development on their own or using specialized companies dealing with the implementation of the concept of lean management in enterprises. Regardless of the way of the implementation of lean culture [62], the way of communication with employees is very important since the approach of the staff to the new way of business management determines the success of its implementation $[63,64]$.

When summing up the characteristics of the concept of lean management, it should be acknowledged that the concept of lean management and sustainable development are connected:

- "Lean management is a specific strategy of the operation of the company, whose most important principle is to eliminate any losses;

- The most significant in lean management is the operation compliant with expectations and requirements of customers and also the demand reported by them;

- The quality should be incorporated into the process;

- Processes should be maximally simplified to become the least sensitive to disturbances coming from the environment;

- The conditions for continuous improvement must be provided for products, processes and employees" $[65,66]$.

The implementation of lean management and modern information technologies enabling lean management in enterprises becomes the necessity in enterprises that want to maintain their market position and, at the same time, implement the assumptions of the concept of sustainable development [67]. Technological progress currently provides modern tools that allow the development and maintenance of lean culture in enterprises. The use of lean culture informs about the decisions made in the enterprise in the implementation of the concept of sustainable development.

\section{The Implementation of Modern Information Technologies in the Field of Lean Management in Enterprises in Terms of Sustainable Development-The Example of DHL}

The use of AR technology in the field of storage and transport are areas of sustainable development, due to the fact that there is a need to optimize reloading processes, which affects the quality of deliveries to customers [68]. However, it generates negative effects in the form of the need to reduce noise, which is burdensome for the local community, as verified by the German company DHL as an area of sustainable development. [69]. The case study was developed on the basis of the data published by the DHL company. Enterprises, in search of increasingly new ways to reduce costs of conducting their activity reach for different tools of the lean management concept [70-72] since they increase the efficiency of implementation of the assumptions of sustainable development in enterprises. According to the DHL company, warehouse operations amount to about $20 \%$ of all logistics costs whereas total packaging costs range from $55-65 \%$ of the total costs of warehouse operations. This leads to the conclusion that packaging is the area in which costs and impact can and should be reduced, resulting in positive social, environmental and economic effects. It increases customer satisfaction, reduces environmental repercussions and, used in devices supporting warehouse management activities, also contributes to increase the performance of warehouse workers while shortening their working time. All the time, some new solutions using AR are being developed. Modern AR devices are used in the warehouse management implemented and thus support the organization in maintaining lean culture and sustainable development in everyday operations.

The devices equipped with AR software for order picking analyze the scope of the order fulfilled, provide an opportunity to recognize objects at real time, enable reading barcodes and part numbers, 
allow indoor navigation and more efficient picking products for shipping. In this way, the employee does not waste their time thinking where various products are located but the device indicates the shortest and most effective way to go to pick products for shipping, which positively affects the reduction in emissions into the atmosphere during the operation of warehouse equipment. The device verifies if the picked items are compliant with the order fulfilled and if their number is correct. The application of devices equipped with AR allows the reduction in the number of errors, facilitates the work of warehouse workers and positively influences an increase in efficiency and effectiveness in the social and economic perspective of sustainable development. Moreover, such devices can be equipped with hands-free kits, which allows for performing freely physical work associated with the preparation of orders for shipping. The situation at DHL is the evidence of the evolution of the concept and practice of sustainable development and its implementation is reflected in both economic, social and environmental effects of the company.

\section{Results and Discussion}

An important advantage of using AR devices in warehouse management is short training time for new employees as the warehouse service since the devices manage and lead the staff to designated places. AR devices may be compatible with other IT systems in the enterprise and enable the optimization of the distribution of products in the warehouse. When referring to the current arrangement of the warehouse space, AR devices may also prove to be suitable in the processes of the warehouse reorganization in order to optimize the distribution of warehouse products. When analyzing the orders fulfilled, one may, for example, recognize which items are packed along with other products and place them nearby. It positively affects the implementation of not only the economic perspective of sustainable development but also the social and environmental one, because it reduces costs, time of handling operations, number of complaints and the pollutants and wastes generated.

In the field of transport optimization, AR devices can verify the whole load of the freight in terms of completeness, e.g., the whole loaded vehicle, with combined scanners and three-dimensional sensors, they can scan products in order to detect possible failure or defects, enable the identification of the classification of commodity codes by means of which they improve the processes of forwarding deliveries from the recipient to the supplier. The devices equipped with AR also support drivers supplying the prepared deliveries, in the form of current data on the situation on the route to the delivery destination displayed within the field of the driver's vision, current route optimization or information concerning the transported load, such as the condition of the content, weight, size or ambient temperature. Improvements offered by AR devices in the field of optimization of costs generated in warehouse management are inscribed in the area of the economic perspective of sustainable development.

Another skill of AR devices is related to the acceleration of the process of loading and unloading and allows for the most optimum packaging of the prepared order directly in a truck or to another type of a means of transport [73-75]. The device analyzes the prepared products in terms of size and volume, however, it shows how and in what order to pack products so as to evenly distribute the load of the whole delivery in a vehicle.

Summing up, it should be pinpointed that the operations of the DHL company on the international arena associated with searching for, testing and implementing augmented reality in the field of optimization of warehouse management give high hopes for many enterprises from this industry. Due to the development of the tools equipped with AR and the existing stage of design of these devices, in spite of many listed advantages, except for the undoubtedly high price, it is difficult to indicate the drawbacks of this solution. Searching for new ways to maintain the culture of lean management and sustainable development in the enterprise allows the achievement of competitive advantage. Therefore, enterprises are willing to reach for modern IT technologies and attempt to use them to implement the concept of sustainable development in their organizations. 


\section{Conclusions}

The clear implication of the presented theoretical assumptions is that the dimension of the sustainable development can be significant for the efficiency of business management, which is in line with the results of the previous studies [21]. This is due to the fact that AR improves efficiency, which increases the satisfaction of customers due to the better quality of products offered, the number of complaints is reduced, and thus the amount of waste is reduced, and the employee's work is more effective. This means that the lack of strategic orientation, in managing sustainable development of the company, may be the reason for the lack of progress in the field of sustainable development [22]. The main contribution of the article is the deeper understanding of the co-existence of benefits, compromises, opportunities and risks related to the implementation of sustainable development management in enterprises. In particular, the advantages and disadvantages of the economic perspective of sustainable development have been explained, which contribute to better understanding the environmental, social and economic values that make up this framework. Thus, the study fills the gap in the discussion of the relationship between the economic, social and environmental perspectives in the concept of sustainable development. The study supports the current view that the balanced approach to business management translates into economic effects, allows for gaining an advantage over competitors by satisfying the needs of customers oriented to sustainable development. In the opinion of the authors, the study comprehensively presents dependencies and relationships between various perspectives of the concept of sustainable development. It should be emphasized that the study provides managers with the overview of instruments important for the integration and implementation of the concept of sustainable development, not only in the implementation of the adopted strategy but also in operational activities.

When referring to the title of the paper, it should be concluded that along with the development of modern technologies in the world, taking into account augmented reality and lean culture, the scope of its application, in the field of implementation of the concept of sustainable development, becomes unlimited. With the help of AR devices, enterprises can expand cooperation with the local community contributing to the fulfillment of their needs, for example in the field of monitoring and security. AR devices can be used to detect wastage in manufacturing processes, which can have a positive effect on reducing pollution, thus reducing costs. The world technological progress and the development of digitization currently provide modern solutions that can be implemented in the field of sustainable development of enterprises, which is a part of the field of management science. Augmented reality changes printed and two-dimensional communication into digital communication, which becomes a new research area in management science. Furthermore, the research into the synthesis of the concept of sustainable development, AR and lean culture in management science is at the initial stage of exploration. The objective of the paper has been accomplished. There have been recognized and assessed augmented reality and lean culture in the field of sustainable development management of enterprises. Moreover, there has been indicated positive impact, not only on cost optimization in enterprises but also on an increase in quality and work efficiency. The discussed examples of the application of augmented reality in enterprises illustrate what measurable benefits may be provided due to the application of the devices equipped with AR for the organization. The conducted research has certain limitations. Due to the fact that extended reality is an innovative solution in the area of management science, it is extremely difficult to carry out comparative research in this area. Moreover, in the paper, attention has been drawn to the risk generated by AR in the area of sustainable development. This risk occurs both in terms of the issue of confidentiality of information about the company and privacy policy or data loss. Nevertheless, the recommendation for enterprises is to increase the scope of implementation of the augmented reality solutions to other areas of the enterprise's activity (e.g. accounting), which may contribute to an increase in the efficiency of assumptions of the concept of sustainable development in the case of permanently changing environment.

Despite the existing restrictions, it should be clearly emphasized that augmented reality enables new improvements, particularly in the area of training, where visualization techniques in a different 
scenery allow for shortening the time of acquisition of the presented knowledge. The considerations clearly show that at the stage of design, augmented reality is used in the form of three-dimensional holograms in different configurations, which fully reflect physical elements. In the process of assembly, the devices equipped with AR facilitate work, leading the user throughout the whole process of assembly, step by step. The devices equipped with AR can be controlled via voice or gesture, which positively influences the optimization of the process of the performed work. Some of the considerations have been presented in general terms, which, on the one hand, allows for highlighting the complexity of the issues being addressed and, on the other, inspires for further research into the potential for shaping and strengthening reality in order to reduce the negative effects of the industrial business activity as a result of the implementation of AR.

Author Contributions: M.Ł.-M. set up the conception and reaserch under H.K. supervision; S.Ł.-Ś. collected the data; M.Ł.-M., H.K. and S.Ł.-Ś. conducted the content analysis; H.K. prepared research methodology; M.Ł.-M. and S.E.-Ś. conducted the case study; M.E.-M. and S.Ł.-Ś. wrote the paper with the help of H.K. The authors have read and approved the final manuscript.

Funding: This research received no external funding.

Conflicts of Interest: The authors declare no conflict of interest.

\section{References}

1. Kates, R.W.; Parris, T.M.; Leiserowitz, A.A. What Is Sustainable Development? Goals, Indicators, Values, and Practice. Environ. Sci. Policy Sustain. Dev. 2012, 47, 8-21.

2. Hamel, G.; Valikangas, L. The Quest for Resilience. Harvard Business Review. 2003. Available online: https:/ /hbr.org/2003/09/the-quest-for-resilience (accessed on 14 September 2018).

3. Nogalski, B. Modele Biznesu Jako Narzędzie Reorientacji Strategicznej Przedsiębiorstw. 2009, p. 4. Available online: https:/ / mbace.eu/api/files/view/1360.pdf (accessed on 10 April 2019).

4. Report of the World Commission on Environment and Development: Our Common Future. Available online: http:/ / www.un-documents.net/our-common-future.pdf (accessed on 13 September 2018).

5. Williams, C.C.; Millington, A.C. The diverse and contested meanings of sustainable development. Geogr. J. 2004, 170, 99-104. [CrossRef]

6. McWilliams, A.; Siegel, D. Corporate Social Responsibility and Financial Performance: Correlation or Misspecification? Strateg. Manag. J. 2000, 21, 603-609. [CrossRef]

7. Knight, E. The Art of Corporate Endurance. Harvard Business Review. 2014. Available online: https: / /hbr.org/2014/ 04/ the-art-of-corporate-endurance (accessed on 14 September 2018).

8. Reis, T.H. Compensation for Environmental Damages under International Law; Wolters Kluwer: Deventer, The Netherlands, 2011.

9. Starik, M.; Kanashiro, P. Toward a Theory of Sustainability Management: Uncovering and Integrating the Nearly Obvious. Organ. Environ. 2013, 26, 7-30. [CrossRef]

10. Larson, B.A. Sustainable Development Research Advances; Nova Science Publishers: New York, NY, USA, 2007; p. 11. Available online: https://books.google.pl/books?hl=pl\&lr=\&id=_9uzFtt4yqsC\&oi=fnd\&pg=PR7\& $\mathrm{dq}=$ Larson, + B.A. + Sustainable+Development+Research+Advances\%3B+Nova+Science+Publishers+2007\& ots=ga6mNL2fN5\&sig=tFov-ipCU-hhJJXF34RW4RzCZtQ\&redir_esc=y\#v=onepage\&q\&f=false (accessed on 10 April 2019).

11. Schaltegger, S.; Lüdeke-Freund, F.; Hansen, E. Business Cases for Sustainability: The Role of Business Model Innovation for Corporate Sustainability. Int. J. Innov. Sustain. Dev. 2012, 6, 95-119. [CrossRef]

12. Rossa, S.A. Sustainable Development Handbook; The Fairmont: London, UK, 2008.

13. Porter, T.; Derry, R. Sustainability and Business in a Complex World. Bus. Soc. Rev. 2012, 117, 33-53. [CrossRef]

14. Bocken, N.M.; Short, S.W.; Rana, P.; Evans, S. A Literature and Practice Review to Develop Sustainable Business Model Archetypes. J. Clean. Prod. 2014, 65, 42-56. [CrossRef]

15. Tladi, D. Sustainable Development in International Law: An Analysis of Key Enviro-Economic Instruments; Pretoria University Law Press: University of Pretoria, South Africa, 2007; p. 74. 
16. Gong, M.; Wall, G. On exergy and sustainable development-Part 2: Indicators and methods. Exergy Int. J. 2001, 1, 217-233. [CrossRef]

17. Lindgreen, A.; Swaen, V. Corporate Social Responsibility. Int. J. Manag. Rev. 2009, 12, 71-89. [CrossRef]

18. Korhonen, J. Theory of Industrial Ecology. Prog. Ind. Ecol. 2004, 1, 61-88. [CrossRef]

19. Macharzina, K.; Wolf, J. Unternehmensführung: Das Internationale Managementwissen. In Konzepte-Methoden-Praxis (Business Management: The International Management Knowledge (Original in German)); Gabler: Wiesbaden, Germany, 2008.

20. Wöhe, G.; Döring, U. Einführung in die Allgemeine Betriebswirtschaftslehre; 26 Auflage; Vahlen: München, Germany, 2008.

21. Kurucz, E.C.; Colbert, B.A.; Wheeler, D. The business case for corporate social responsibility. In The Oxford Handbook on Corporate Social Responsibility; Oxford University Press: Oxford, UK, 2008.

22. Baumgartner, R.J.; Rauter, R. Strategic Perspectives of Corporate Sustainability Management to Develop a Sustainable Organization. J. Clean. Prod. 2017, 140, 81-92. [CrossRef]

23. Baumgartner, R.J. Managing corporate sustainability and CSR: A conceptual framework combining values, strategies and instruments contributing to sustainable development. Corp. Soc. Responsib. Environ. Manag. 2014, 21, 258-271. [CrossRef]

24. Baumgartner, R.J.; Korhonen, J. Strategic thinking for sustainable development. Sustain. Dev. 2010, 18, 71-75. [CrossRef]

25. Linnenluecke, M.K.; Griffith, A. Corporate sustainability and organizational culture. J. World Bus. 2009, 45, 357-366. [CrossRef]

26. Hein, D.W.E.; Jodoin, J.L.; Rauschnabel, P.A.; Ivens, B.S. Are Wearables Good or Bad for Society?: An Exploration of Societal Benefits, Risks, and Consequences of Augmented Reality Smart Glasses. In Mobile Technologies and Augmented Reality in Open Education; University of Michigan: Dearborn, MI, USA, 2017; pp. 1-25.

27. Hein, D.W.; Rauschnabel, P.A. Augmented Reality Smart Glasses and Knowledge Management: A Conceptual Framework for Enterprise Social Networks. In Enterprise Social Networks; Springer Fachmedien: Wiesbaden, Germany, 2016; pp. 83-109. Available online: https:/ / www.springerprofessional. de/en/augmented-reality-smart-glasses-and-knowledge-management-a-conce/10254420 (accessed on 10 April 2019).

28. Baumgartner, R.J.; Zielowski, C. Analyzing zero emission strategies regarding impact on organizational culture and contribution to sustainable development. J. Clean. Prod. 2007, 15, 1321-1327. [CrossRef]

29. Hinterhuber, H.H. Strategische Unternehmensführung; Walter de Gruyter: Berlin, Germany, 2004.

30. Michelon, G.; Boesso, G.; Kumar, K. Examining the link between strategic corporate social responsibility and company performance: An analysis of the best corporate citizens. Corp. Soc. Responsib. Environ. Manag. 2012, 20, 81-94. [CrossRef]

31. Schiederig, T.; Tietze, F.; Herstatt, C. Green innovation in technology and innovation management e an exploratory literature review. RED Manag. 2012, 42, 2180-2192.

32. Patton, M.Q. Qualitative Evaluation Methods; Sage Publications, Inc.: Thousand Oaks, CA, USA, 1980.

33. Yin, R.K. The Case Study as a Serious Research Strategy. Sci. Commun. 1981, 3, 97-114. [CrossRef]

34. Czakon, W. Podstawy Metodologii Badań w Naukach o Zarzadzaniu; Oficyna a Wolters Kluwer Business: Warszawa, Poland, 2015; pp. 158-229.

35. Gibbert, M.; Ruigrok, W.; Wicki, B. What passes as a rigorous case study? Strateg. Manag. J. 2008, 29, 1465-1474. [CrossRef]

36. Eisenhardt, K.M.; Graebner, E. Theory building from cases: Opportunities and challenges. Acad. Manag. J. 2007, 50, 25-32. [CrossRef]

37. Teplická, K.; Čulková, K.; Železník, O. Application of Bayess Principle Optimum-Optimization Model for Managerial Decision and Continual Improvement. Pol. J. Manag. Stud. 2015, 12, 170-179.

38. McKinsey\&Company. Industry 4.0. How to Navigate Digitization of the Manufacturing Sector. 2015. Available online: https://www.mckinsey.de/files/mck_industry_40_report.pdf (accessed on 16 September 2016).

39. Lee, J.; Kao, H.; Yang, S. Service Innovation and Smart Analytics for Industry 4.0 and Big Data Environment. In Proceedings of the 6th CIRP Conference on Industrial Product-Service Systems, Windsor, ON, Canada, 1-2 May 2014; pp. 3-8. Available online: https:/ / pdfs.semanticscholar.org/d2dd/ 384dc904c631f4debb8bbc1edb216e85627e.pdf (accessed on 10 April 2019). 
40. Porter, M.E. Augmented Reality; Harvard Business Review Poland: Warszawa, Poland, 2018; p. 44.

41. Carmigniami, J.; Furht, B. Augmented Reality: An Overview. In Handbook of Augmented Reality; Springer: New York, NY, USA, 2011; pp. 3-46.

42. Azuma, R.T. A Survey of Augmented Reality, Teleoperators and Virtual Environments MIT. 1997, pp. $355-385$. Available online: https:/ / www.cs.unc.edu/ \{\}azuma/ARpresence.pdf (accessed on 10 April 2019).

43. Bainbridge, W.S. The Scientific Research Potential of Virtual Worlds. Science 2007, 317, 472-476. [CrossRef]

44. Benderson, B.B. Audio Augmented Reality: A Prototype Automated Tour Guide Archived. In Proceedings of the Wayback Machine, Bell Communications Research, ACM Human Computer in Computing Systems Conference, Seoul, Korea, 15 November 2012; pp. 210-211.

45. Stuart, E. Augmenting Phenomenology: Using Augmented Reality to Aid Archaeological Phenomenology in the Landscape. J. Archaeol. Method Theory 2012, 19, 582-600.

46. Novak-Marcincin, J.; Barna, J.; Janak, M.; Novakova-Marcincinova, L. Augmented reality aided manufacturing. Procedia Comput. Sci. 2013, 25, 23-31. [CrossRef]

47. Van Krevelen, D.W.F.; Poelman, R. A survey of augmented reality technologies, applications and limitations. J. Virtual Reality 2010, 9, 1-20. Available online: http:/ / citeseerx.ist.psu.edu/viewdoc/download?doi=10.1.1. 454.8190\&rep=rep1\&type=pdf (accessed on 11 April 2019).

48. Circulis, A.; Ginters, E. Augemnted Reality in logistics. Procedia Comput. Sci. 2013, 26, 14-20. [CrossRef]

49. Łegowik-Świącik, S.; Grabowska, M. Opportunities for Application of Modern Instruments of Management in the Field of Green Logistics; The Publications of the MultiScience; microCAD: Miskolc, Hungary, 2014; p. 7.

50. Shah, R.; Ward, P.T. Lean Manufacturing: Context, Practice Bundles, and Performance. J. Oper. Manag. 2003, 21, 129-149. [CrossRef]

51. Nogalski, B. Lean Management. In Koncepcje zarzadzania; Wydawnictwo C. H. Beck: Warszawa, Poland, 2010; pp. 300-320.

52. Holweg, M. The Genealogy of Lean Production. J. Oper. Manag. 2007, 25, 420-437. [CrossRef]

53. Czarniewski, S. Small and medium-sized enterprises in the context of innovation and entrepreneurship in the economy. Pol. J. Manag. Stud. 2016, 13, 30-39. [CrossRef]

54. Womack, J.P.; Jones, D.T.; Roos, D. The Machine that Changed The Word; Free Press: Sydney, Australia, 1990.

55. Nguyen Minh, D. A New Decision Making Model Based on the Made in Vietnam Lean Management Philosophy. Econ. Sociol. 2018, 11, 44-60.

56. Womack, J.P.; Jones, D.T. Lean Thinking—Szczupłe Myślenie; ProdPress: Wrocław, Poland, 2008; pp. 19-44.

57. Minh, N.D. A New Application Model of Lean Management in Small and Medium Sized Enterprises. Int. J. Simul. Model. 2015, 14, 289-298.

58. Romanowska, M. Determinanty innowacyjności polskich przedsiębiorstw. Przegląd Organ. 2016, 2, $29-35$.

59. Kubis, N. Narzędzia lean management. Zagadnienia Tech. Ekono. 2005, 50, 291-303.

60. Imai, M. Gamba Kazein, A Commonsense Approach to a Continuous Improvement Strategy; McGraw-Hill: New York, NY, USA, 2012; p. 36.

61. Bilton, C.; Cummings, S. Creative Strategy: Reconnecting Business and Innovation; John Wiley and Sons: Chichester, UK, 2010; pp. 14-23.

62. Jelonek, D.; Dondela, M. Wpływ Stylów Kierowania i Implementalność Koncepcji Lean Management. In Materialne i Niematerialne Aspekty Inżynierii Produkcji; Oficyna Wydawnicza Stowarzyszenia Menedżerów Jakości i Produkcji: Częstochowa, Poland, 2016; pp. 91-103.

63. Cooney, R. Is Lean a Universal Production System? Int. J. Oper. Prod. Manag. 2002, 22, 1130-1147. [CrossRef]

64. Pettersen, J. Defining lean production: Some conceptual and practical issues. TQM J. 2009, 21, 127-142. [CrossRef]

65. Jakubowski, J.; Woźniak, W.; Stańkowska, M. Lean Management-Efektywne Zarządzanie Operacyjne w Praktyce. Prace Naukowe WSZIP 2017, 40, 17-29.

66. Starzyńska, B.; Hamrol, A. Excellence toolbox: Decision support system for quality tools and techniques selection and application. J. Total Qual. Manag. Bus. Excellence 2013, 24, 577-595. [CrossRef]

67. Kot, S. Transport Activity Costs in the Aspect of Applied Information Technology. In Proceedings of the 5th IEEE International Conference on Advanced Logistics and Transport (IEEE ICALT'2016), Kraków, Polska, 1-3 June 2016; pp. 1-6.

68. Grabara, J.; Kolcun, M.; Kot, S. The Role of Information Systems in Transport Logistics. Int. J. Educ. Res. 2014, $2,1-8$. 
69. Augmented Reality in Logistics Changing the Way We See Logistics-A DHL Perspective 2014. Available online: https:/ / www.logistics.dhl/us-en/home/insights-and-innovation/thought-leadership/ trend-reports/augmented-reality.html (accessed on 27 April 2018).

70. Christopher, M. Logistics and Supply Chain Management; FT Press: London, UK, 2011; pp. 2-15.

71. Carter, C.R.; Easton, P.L. Sustainable Supply Chain Management: Evolution and Future Directions. Int. J. Phys. Distrib. Logist. Manag. 2011, 41, 46-62. [CrossRef]

72. Blewitt, J. Understanding Sustainable Development; Routledge: New York, NY, USA, 2014.

73. Morali, O.; Searcy, C. A Review of Sustainable Supply Chain Management Practices in Canada. J. Bus. Eth. 2013, 117, 635-658. [CrossRef]

74. Dima, I.C.; Grabara, J.; Modrak, V. Sustainable logistics and business competitiveness. Int. Lett. Soc. Hum. Sci. 2014, 15, 148-156. [CrossRef]

75. Coombs, J.E.; Sadrieh, F.; Annavarjula, M. Two decades of international entrepreneurship research: What have we learned-where do we go from here? Int. J. Entrep. 2009, 13, 23-64.

(C) 2019 by the authors. Licensee MDPI, Basel, Switzerland. This article is an open access article distributed under the terms and conditions of the Creative Commons Attribution (CC BY) license (http:/ / creativecommons.org/licenses/by/4.0/). 